\title{
Estimates of stroke incidence and case fatality in Zabrze, 2005-2006
}

\section{Wskaźniki zapadalności i śmiertelności w udarze mózgu w populacii mieszkańców Zabrza w latach 2005-2006}

Maciej Wawrzyńczyk', Krystyna Pierzchała', Bogumiła Braczkowska², Iwona Mańka-Gaca', Klaudiusz Kumor', Daniel Borowski³, Lucyna Grodzicka-Zawisza ${ }^{3}$, Jan Zejda ${ }^{2}$

${ }^{1}$ Klinika Neurologii w Zabrzu, Ślaski Uniwersytet Medyczny

2Katedra Epidemiologii, Śląski Uniwersytet Medyczny

30ddział Neurologii, Szpital Rejonowy w Zabrzu

Neurologia i Neurochirurgia Polska 2011; 45, 1: 3-10

\begin{abstract}
Background and purpose: Epidemiological rates for stroke obtained in the United States and Western Europe indicate a decrease in incidence and case fatality. Data published for Poland, as for other Central-Eastern European countries, reported unfavourable results, but this was based on data from the 1990s. The authors evaluated current stroke rates in a population study of the southern Poland city of Zabrze.
\end{abstract}

Material and methods: A retrospective registry of all stroke cases treated in Zabrze, southern Poland, in 2005-2006, was established, based on data from the National Health Fund. Cases were identified by verifying patient files. Epidemiological rates were calculated and standardized to the European population in both groups: all stroke patients, including recurrent (all strokes, AS), and patients with first-ever stroke (FES) in their history.

Results: We registered 731 strokes, including 572 FES cases $(78.3 \%)$ and 159 recurrent strokes (21.7\%). There were 385 strokes in men (52.7\%), and 346 in women (47.2\%); $88.6 \%$ were ischaemic strokes (IS), and $11.4 \%$ were intracerebral haemorrhages $(\mathrm{ICH})$. The standardized incidence rate for AS patients was 167/100 000 (211 for men, 130 for women), and in the FES group 131/100 000 (161 for men, 104 for women). Twenty-eight day case fatality for the AS

\section{Streszczenie}

Cel pracy: Wskaźniki epidemiologiczne dotyczące udaru mózgu uzyskane w USA i Europie Zachodniej wykazują spadek zapadalności oraz śmiertelności. Dane publikowane w Polsce, podobnie jak w innych krajach Europy Środkowo-Wschodniej, są znacznie bardziej niekorzystne, pochodza jednak z badań prowadzonych w latach 90 . Autorzy ocenili aktualne wskaźniki epidemiologiczne w udarze mózgu w badaniu obejmującym populację miasta Zabrze w południowej Polsce. Materiał i metody: $\mathrm{Na}$ podstawie danych pozyskanych z Narodowego Funduszu Zdrowia utworzono retrospektywny rejestr chorych leczonych $\mathrm{z}$ powodu udaru mózgu w Zabrzu w latach 2005-2006. Dane weryfikowano, analizując dokumentację chorych. Wskaźniki epidemiologiczne poddano standaryzacji dla populacji europejskiej w dwóch grupach pacjentów: wszystkich chorych z udarem oraz chorych z pierwszym w życiu udarem.

Wyniki: Do rejestru włączono 731 chorych -572 chorych z pierwszym w życiu udarem $(78,3 \%)$ i 159 (21,7\%) z udarem nawracającym. Zarejestrowano 385 udarów wśród mężczyzn (52,7\%) i 346 wśród kobiet (47,2\%). U 88,6\% chorych stwierdzono udar niedokrwienny (UN), a u $11,4 \%$ krwotok śródmózgowy (KŚ). Zapadalność w grupie AS wynosiła 167/100 000 (211 wśród mężczyzn, 130 wśród kobiet), w grupie FES - 131/100 000 (odpowiednio 161

Correspondence address: dr Maciej Wawrzyńczyk, Klinika Neurologii, Śląski Uniwersytet Medyczny, ul. 3 maja 13-15, 41-800 Zabrze, e-mail: mcwaw@mp.pl

Received: 18.02.2010; accepted: 26.10.2010 
group was $18.3 \%$ (15.4\% for IS, $41 \%$ for ICH), and $16.6 \%$ for FES (13.4\% for IS, $40.9 \%$ for ICH).

Conclusions: Incidence rates in this southern Poland city are comparable to those reported previously for Poland. Early case fatality decreased, compared to previous data, probably as a result of improved management of acute stroke and hospitalizing all stroke patients.

Key words: epidemiology, incidence rate, case fatality, stroke.

\section{Introduction}

Stroke remains a major cause of death and permanent disability in most developed countries [1]; approximately 60000 people suffer from stroke in Poland each year. Population-based studies in the USA and Western Europe showed continued decrease of incidence, case fatality and stroke mortality [2-5], although results for the former rate are divergent in the last decade $[6,7]$. In Central-Eastern Europe obtained values were much more unfavourable. In most countries incidence rates and case fatality continued to be high or even increased [8-10]. In Poland, a community-based study from the 1990s revealed a very high case fatality and incidence rate compared with Western countries [11]. It was explained by the poor neurological condition at the onset of stroke, prevalence of numerous risk factors, especially cardiogenic, and more frequent complications of Polish acute stroke patients $[12,13]$. Yet, in the last decade stroke care in Poland has greatly improved, including implementation of a stroke unit network, giving hope for declining stroke rates $[14,15]$. We decided to establish a stroke registry for 2005-2006, to investigate the current incidence rate and case fatality in the city of Zabrze, in southern Poland.

\section{Material and methods}

\section{Population studied and local stroke service}

Zabrze, with an area of $80.2 \mathrm{~km}^{2}$ and a stable population of about 190000 inhabitants in the analysed years, is part of a large industrial conurbation in the Silesian Voivodship, with more than 5000000 citizens living in more than 20 cities. The percentages of women $(51.6 \%)$ and people older than 65 years $(13.65 \%)$ are i 104). Dwudziestoośmiodniowa śmiertelność w grupie AS wyniosła 18,3\% (15,4\% dla udaru niedokrwiennego, $41 \%$ dla krwotoku śródmózgowego), w grupie FES - 16,6\% (odpowiednio $13,4 \%$ i 40,9\%).

Wnioski: Wskaźniki zapadalności na udar mózgu uzyskane w populacji Zabrza są porównywalne z publikowanymi w krajach Europy Zachodniej. Wczesna śmiertelność zmniejszyła się, w odniesieniu do wcześniejszych danych, najpewniej $\mathrm{w}$ następstwie skuteczniejszego postępowania w ostrej fazie udaru oraz hospitalizacji wszystkich chorych.

Słowa kluczowe: epidemiologia, zapadalność, śmiertelność, udar mózgu.

very similar to the numbers for the whole country ( $51.7 \%$ and $13.04 \%$, respectively), and are therefore representative for the demographic structure of Poland as a whole (Central Statistical Office, 31 XII 2006) $[16,17]$.

There are two neurological departments within the city, with a total of more than 80 beds: the Neurological Department with Stroke Unit, in Silesian Medical University Hospital, admitting most stroke patients, and the Neurological Ward in the District Hospital. According to the local practice, patients suspected of stroke, and also residents from nursing homes, are transferred by ambulance service to the neurological wards, so it is very uncommon for them to be treated at home by general practitioners or by the outpatient neurological service. Due to small distances, time-to-door is usually no longer than 20 minutes.

\section{Case identifications}

We established a retrospective stroke registry covering 2005-2006, based on data obtained from the regional Silesian Office of the National Health Fund (NHF), the only public insurance company in Poland. All health services in Zabrze, outpatient clinics and hospitals, are obliged to transfer online to NHF all patient data, including personal data, type of medical procedures performed and diagnosis according to the International Classification of Diseases, $10^{\text {th }}$ revision (ICD-10). We retrieved data comprising all patients with diagnosis codes I61, I63 and I64, hospitalized or treated as outpatients, in Zabrze health services in the analysed years. Patients with transient ischaemic attacks (TIA), coded as G45, were not included in the registry. We also decided to exclude patients with subarachnoid haemorrhage (I60 according to ICD-10) in Zabrze they are diagnosed by neurologists in the Emergency Departments of both hospitals mentioned above, 
with computed tomography (CT) imaging and/or lumbar puncture performed, and next transferred and hospitalized in one of the neurosurgery wards located in other cities, because of the lack of a neurosurgery ward in Zabrze. As we analysed data of patients treated in health services in Zabrze, data of subarachnoid haemorrhage (SAH) patients could not be retrieved from the NHF.

\section{Hospitalized cases}

Study neurologists (K.P., M.W., I.M., K.K., D.B., L.G.-Z.) verified all stroke diagnoses by careful review of patients' history files. They also qualified episodes as first-ever stroke (FES) or recurrent patients without prior history of stroke confirmed by recorded history were included in the FES group, even if CT revealed previous vascular lesions. Clinical data, including age, risk factors, CT results, duration of hospitalization and modified Rankin Scale (mRS) at discharge, were recorded.

\section{Hospital refusals}

Checking the registry, we found no acute stroke patient refusals within the analysed years. To confirm this fact, the files of Emergency Department refusals in hospitals with Neurological Departments were verified with the same result.

\section{Outpatient cases}

Based on NHF data, we reviewed outpatient files for patients with ICD-10 codes I61, I63, I64. Using this methodology we found no new stroke cases treated in an outpatient setting in the analysed period; all patients were directly sent to neurological departments. For confirmation, all neurologists at city outpatient services were questioned if any new stroke patients were treated at home or nursing homes within both years, with a negative answer.

\section{Statistical methods}

Epidemiological rates were calculated for the population on December 31, 2005 and standardized for sex and age using the European standard population. Incidence was analysed for all strokes (AS) and separately for the FES group. Case fatality rate was defined as the proportion of fatal strokes within 28 days of stroke onset, by verification of death certificates in the Registry Office.
All clinical data were entered in the database and calculated using STATISTICA 7.0. Normality of continuous variables was checked by the Shapiro-Wilk test, confirming normality of distribution of analysed values. Student's $t$-test was applied for parametric variables and Pearson's $\chi^{2}$ test for cross-tabulated data. Statistical significance was assumed when $p<0.05$.

\section{Results}

According to accepted criteria, 736 strokes were included in the registry, but finally we excluded 5 cases ( 1 case in 2005, 4 in 2006), all coded as I64 according to ICD-10. All those patients were treated in internal wards and stroke was not their primary diagnosis. One of those patients died within the first day of hospitalization and necropsy was not performed. The other four were treated for other conditions and suspicion of stroke was stated only after a single neurological examination and not confirmed by either subsequent examination or neuroimaging. The remaining 731 patients were hospitalized in neurological wards.

During the analysed years, we identified 648 ischaemic strokes (IS) $(\mathrm{I} 63,88.6 \%)$ and 83 intracerebral haemorrhages $(\mathrm{ICH})(\mathrm{I} 61,11.4 \%)$. After the exclusion mentioned above, we did not identify any patients with I64 code. There were 385 men (52.7\%) and 346 women $(47.3 \%)$ in our registry. Mean age at the onset of stroke was $69.4 \pm 12.4$ years; men were younger than women $(65.9 \pm 11.6$ vs. $73.2 \pm 12.3$ years, $p<0.05)$. FES was diagnosed in 572 cases $(78.3 \%)$ and 159 cases were classified as recurrent strokes $(21.7 \%)$. The proportion of IS and ICH in the FES group was the same as in AS patients, and men were also younger in the FES group $(65.1 \pm 11.9$ vs. $72.8 \pm 12.6$ years, $p<0.05)$. Brain CT was performed in 701 cases $(95.9 \%)$, with 679 examinations on the day of admission (92.9\%). In the remaining 30 cases $(4.1 \%)$ the diagnosis was based only on clinical symptoms.

Mean hospitalization time was $16.3 \pm 11.3$ days; for surviving patients it was $17.9 \pm 11.1$ days. Patients with fatal outcome died after $9.0 \pm 9.2$ days. Three hundred and fifty-seven patients $(48.8 \%)$ achieved mRS score $0-2$ at discharge, being fully or considerably independent.

\section{Incidence rates}

The population of Zabrze was stable within the examined years (191247 inhabitants in 2005, 190110 in 2006, according to the Statistical Office). Age and 
sex distributions of cases in both AS and FES groups are given in Table 1.

The crude annual incidence rate in the AS group was 192 per 100000 population; after standardization to the European population it was $167 / 100000$. For FES stroke patients incidence rates were 150 per 100000 and 131/100 000, respectively. Age- and sexspecific incidence rates are given in Table 2 . They increased in both sexes with each decade of age, with peak values in $>84$ age groups.

\section{Twenty-eight-day case fatality}

Among AS patients, 134 patients died (69 in 2005,65 in 2006). Overall case fatality was $18.3 \%$, being lower for IS patients than for ICH patients $(15.4 \%$ vs. $41.0 \%, p<0.05)$. Age and sex distribution of fatal cases are given in Table 3. Men died at a younger age than women $(70.4 \pm 9.5$ vs. $75.4 \pm$ 14.3 years, $p<0.05)$. Among FES patients, 95 died (49 and 46 in 2005 and 2006, respectively). Twentyeight-day case fatality in this group was $16.6 \%$ (IS $13.4 \%$, ICH $40.9 \%, p<0.05$ ). Among these patients, the difference in mean age between men and women was not significant $(70.6 \pm 9.8$ vs. $74.2 \pm$ 15.4 years, $p=0.17$ ). In both AS and FES groups, case fatality rates were higher for men, but this difference was not significant $(21 \%$ vs. $15.3 \%$ in the former group, $p=0.097,17.9 \%$ vs. $15.2 \%$ in the latter group, $p=0.39$ ).

Table 1. Age and sex distribution of stroke patients in Zabrze (2005-2006)

\begin{tabular}{|c|c|c|c|c|c|c|c|c|c|}
\hline \multirow{2}{*}{$\begin{array}{l}\text { Age } \\
\text { group, } \\
\text { years }\end{array}$} & \multicolumn{3}{|c|}{ Population } & \multicolumn{3}{|c|}{ All strokes } & \multicolumn{3}{|c|}{ First-ever strokes } \\
\hline & $\begin{array}{c}\text { Men } \\
n\end{array}$ & $\begin{array}{c}\text { Women } \\
n\end{array}$ & $\begin{array}{c}\text { Total } \\
n\end{array}$ & $\begin{array}{c}\text { Men } \\
n\end{array}$ & $\begin{array}{c}\text { Women } \\
n\end{array}$ & $\begin{array}{c}\text { Total } \\
n\end{array}$ & $\begin{array}{c}\text { Men } \\
n\end{array}$ & $\begin{array}{c}\text { Women } \\
n\end{array}$ & $\begin{array}{c}\text { Total } \\
n\end{array}$ \\
\hline$<34$ & 43174 & 43398 & 86572 & 2 & 2 & 4 & 2 & 2 & 4 \\
\hline $35-44$ & 14235 & 13953 & 28188 & 8 & 5 & 13 & 8 & 5 & 13 \\
\hline $45-54$ & 15652 & 15655 & 31307 & 62 & 26 & 88 & 55 & 21 & 76 \\
\hline $55-64$ & 9432 & 10494 & 19926 & 85 & 38 & 123 & 70 & 29 & 99 \\
\hline $65-74$ & 7268 & 9134 & 16402 & 131 & 103 & 234 & 93 & 81 & 174 \\
\hline $75-84$ & 2385 & 4650 & 7035 & 81 & 115 & 196 & 57 & 96 & 153 \\
\hline$>84$ & 440 & 1377 & 1817 & 16 & 57 & 73 & 11 & 42 & 53 \\
\hline Total & 92586 & 98661 & 191247 & 385 & 346 & 731 & 296 & 276 & 572 \\
\hline
\end{tabular}

Table 2. Age- and sex-specific incidence rates for all strokes and first-ever strokes per 100000 population in Zabrze

\begin{tabular}{|c|c|c|c|c|c|c|}
\hline \multirow{2}{*}{$\begin{array}{l}\text { Age } \\
\text { group, } \\
\text { years }\end{array}$} & \multicolumn{3}{|c|}{ All strokes } & \multicolumn{3}{|c|}{ First-ever strokes } \\
\hline & $\begin{array}{c}\text { Men } \\
n\end{array}$ & $\begin{array}{c}\text { Women } \\
n\end{array}$ & $\begin{array}{c}\text { Total } \\
n\end{array}$ & $\begin{array}{c}\text { Men } \\
n\end{array}$ & $\begin{array}{c}\text { Women } \\
n\end{array}$ & $\begin{array}{c}\text { Total } \\
n\end{array}$ \\
\hline$<35$ & 2 & 2 & 2 & 2 & 2 & 2 \\
\hline $35-44$ & 28 & 18 & 23 & 28 & 18 & 23 \\
\hline $45-54$ & 198 & 83 & 141 & 176 & 67 & 121 \\
\hline $55-64$ & 451 & 181 & 309 & 371 & 138 & 248 \\
\hline $65-74$ & 901 & 564 & 713 & 640 & 443 & 530 \\
\hline $75-84$ & 1698 & 1237 & 1393 & 1195 & 1032 & 1087 \\
\hline$>84$ & 1818 & 2070 & 2009 & 1250 & 1525 & 1458 \\
\hline Total & 208 & 175 & 191 & 160 & 140 & 150 \\
\hline $\begin{array}{l}\text { Standardized } \\
\text { to European population }\end{array}$ & 211 & 130 & 167 & 161 & 104 & 131 \\
\hline
\end{tabular}


Table 3. Age and sex distribution of fatal cases in stroke patients in Zabrze

\begin{tabular}{|c|c|c|c|c|c|c|}
\hline \multirow{2}{*}{$\begin{array}{l}\text { Age } \\
\text { group, } \\
\text { years }\end{array}$} & \multicolumn{3}{|c|}{ All strokes } & \multicolumn{3}{|c|}{ First-ever strokes } \\
\hline & $\begin{array}{l}\text { Men } \\
n(\%)\end{array}$ & $\begin{array}{c}\text { Women } \\
n(\%)\end{array}$ & $\begin{array}{l}\text { Total } \\
n(\%)\end{array}$ & $\begin{array}{l}\text { Men } \\
n(\%)\end{array}$ & $\begin{array}{c}\text { Women } \\
n(\%)\end{array}$ & $\begin{array}{l}\text { Total } \\
n(\%)\end{array}$ \\
\hline$<34$ & $0(0.0)$ & $0(0.0)$ & $0(0.0)$ & $0(0.0)$ & $0(0.0)$ & $0(0.0)$ \\
\hline $35-44$ & $0(0.0)$ & $2(3.8)$ & $2(1.5)$ & $0(0.0)$ & $2(4.8)$ & $2(2.1)$ \\
\hline $45-54$ & $5(6.2)$ & $3(5.7)$ & $8(6.0)$ & $4(7.5)$ & $3(7.1)$ & $7(7.4)$ \\
\hline $55-64$ & $16(19.8)$ & $3(5.7)$ & $19(14.2)$ & $12(22.6)$ & $3(7.1)$ & $15(15.8)$ \\
\hline $65-74$ & $33(40.7)$ & $12(22.6)$ & $45(33.6)$ & $20(37.7)$ & $8(19.1)$ & $28(29.5)$ \\
\hline $75-84$ & $23(28.4)$ & $21(39.6)$ & $44(32.8)$ & $15(28.4)$ & $17(40.5)$ & $32(33.7)$ \\
\hline$>84$ & $4(4.9)$ & $12(22.6)$ & $16(11.9)$ & $2(3.8)$ & $9(21.4)$ & $11(11.6)$ \\
\hline Total & 81 & 53 & 134 & 53 & 42 & 95 \\
\hline
\end{tabular}

\section{Discussion}

\section{Quality of case ascertainment}

We estimated epidemiological rates, using retrospective data obtained from the National Health Fund. Although this methodology is not in agreement with 'ideal' criteria for epidemiological studies, proposed by Sudlow and Warlow [18], we hope that the risk of underestimation is very low.

The system of public health care in the Silesian Voivodship requires transferring data, including the obligatory ICD-10 code, to the NHF computer database, just after any outpatient or hospital procedures are performed, as it is the only way for all health services to be refunded. Because all citizens are insured in the NHF, its data comprise all medical incidents in the population.

Our registry was based on all episodes, ambulatory or hospitalized, registered in health care facilities in the city of Zabrze, coded as strokes (i.e. I61, I63 and I64 according to ICD-10) except subarachnoid haemorrhages (SAH). We reviewed outpatient data, although previous studies in Poland revealed a very low rate of non-hospitalized patients, below 2\% [19]. As mentioned above, verifying patients' ambulatory files and emergency ward refusals, we found no new stroke cases treated as outpatients or not hospitalized after examination in emergency wards. This practice of sending all patients suspected of stroke to neurological wards was confirmed by outpatient neurologists. All cases classified as new stroke were treated in either the Stroke Unit in the Medical University Hospital or the Neurological Ward in the District Hospital.
A source of possible underestimation may be fatal cases of sudden death without medical examination or patients dying at home, usually old or chronically ill. However, in such cases the diagnosis remains uncertain, being usually based on previous clinical data or details given by relatives or witnesses, in most cases without autopsy, especially in the latter group. So it can be a source of both over- and underreporting, with no significant impact on epidemiological rates. In our registry, the number of fatal cases in the oldest age group was low, but we think this was due to the decreased population size, especially in men.

Another reason for underestimation may be not identifying stroke patients without any contact with health care facilities. In one of the latest studies [20] the percentage of stroke cases registered only during daily rounds made by volunteers in the studied area was about $10 \%$. Yet in this population, the hospitalization rate was only $66 \%$, whereas in our study all identified stroke patients were hospitalized, probably due to relatively easy access to neurological care in Zabrze and awareness among general practitioners of the necessity of hospital treatment for acute stroke.

The decision not to include $\mathrm{SAH}$ patients reduced the total incidence rate. However, in a previous community-based study in Poland [11] the authors also excluded SAH patients, and following this methodology enabled us to compare epidemiological rates. Excluding SAH patients could also affect the total case fatality rate. Yet in numerous population-based studies in Europe the proportion of SAH patients remains between $3 \%$ to $7 \%$ of all strokes $[4,6,7,17]$, so despite 
the high death percentage in this group of patients, reaching about $40-45 \%$, it would have had only a slight influence on our total case fatality rate.

For hospitalized patients, all their records were reviewed and 5 cases with uncertain diagnosis were excluded, due to insufficient clinical data. More than 95\% of hospitalized patients had brain CT performed, so we could precisely estimate the proportion of IS and $\mathrm{ICH}$ and case fatality for both main types of stroke.

\section{Comparisons with other studies}

\section{Incidence rate}

Population-based studies performed in the USA and Western Europe in the second half of the $20^{\text {th }}$ century revealed that incidence rates were constantly declining or remained stable at around 100/100 000 for FES strokes. However, results obtained for Central-Eastern Europe in the last two decades showed incidence rates being still high [9-11] or even increasing [8], with average age-adjusted incidence rates over 200/100 000. Previous results for Poland, from the 1991-1992 Warsaw Stroke Registry (WSR) community-based study [11] (149/100 000 for all strokes, 111/100 000 for FES) were similar to those in developed regions: Rochester [2], Oxfordshire [4], or Dijon [6]. In 1999-2000, other Polish authors in Cracow [21], in a hospital-based study, estimated higher rates (180/100 000 for AS strokes) but in this study SAH patients were included. If we want to compare these values to our results we must take into consideration possible underestimation due to the retrospective design of our study. However, incidence rates established for Zabrze are close to rates obtained in the WSR regarding the AS group and are slightly higher for FES strokes. In our registry, the proportion of recurrent strokes was lower than in the WSR $(21.7 \%$ vs. $27.3 \%$ ), probably due to improved methods of prevention of subsequent stroke. Those results suggest that, despite the different methodology of case identification in these studies (prospective community-based in Warsaw, hospital-based in Cracow, retrospective revision of data from the NHF in Zabrze), incidence rates remain rather stable in Poland. This was also confirmed by recently published data, as part of the results of the EROS study, for stroke incidence in the population of Warsaw [22]. After excluding SAH episodes, incidence rates established by EROS investigators, based on data collected in 2005, were only slightly higher than in the WSR (139.1/100 000 in comparison with 134/100 000 for men, 120.6/100 000 in comparison with 91/100 000 for women). Our results, obtained for the Zabrze population, are higher for men and lower for women. In comparison to EROS results for other countries, ranging from 101.2 to 239.3 in men and from 63.0 to 158.7/100 000 in women, they are higher than incidence rates in Western and lower than in Eastern European countries.

There are several reasons limiting the decline in stroke incidence in Poland. One of the most important is the still unsatisfactory control of risk factors. In the Polish National Stroke Prevention and Treatment Registry, collecting data from 26 centres, treating more than 8700 acute ischaemic stroke patients in years 2001-2002, $18 \%$ of patients with hypertension were not treated before stroke and $46 \%$ of patients with a history of stroke or myocardial infarction were not given antiplatelets. Less than 10\% of atrial fibrillation patients were prescribed anticoagulants and only about $40 \%$ of patients with hyperlipidaemia received statins prior to stroke.

On the other hand, an important factor that probably restricted the decrease in stroke incidence in Poland was better detection of stroke, especially due to better access to CT scanning. This phenomenon was observed for the first time in the Rochester study, being responsible for increasing stroke rates in the late eighties [23]. In the WSR registry, only less than $60 \%$ of all patients had CT performed, as the number of CT scanners was definitely insufficient. In the Polish National Stroke Prevention and Treatment Registry, collecting data from the period about 10 years later, CT or MRI was done in $87 \%$ of stroke patients. Among patients in our registry almost $96 \%$ of stroke patients were CT scanned.

\section{Case fatality}

Results from the MONICA study revealed very unfavourable mortality rates for stroke in Central-Eastern European countries, especially in Poland, as a consequence of very high case fatality, although incidence rates were comparable [3]. Whereas in industrialized countries case fatality declined to below $20 \%$ in the 1980 s and remained stable in subsequent decades $[3,4,24]$, rates reported for regions with transition economies still remain high: $30 \%$ in Estonia [8], 30.6\% in Russia [9], 23.3\% in Ukraine [10]. The rate for Poland established in the 1990s in the WSR study was even higher (40\%), although this was partly due to including stroke cases based on death certificates (for hospitalized patients only, case fatality in the WSR was 
31.6\%) [11]. However, other rates for Poland based on results from the 1990s were also considerably higher than in Western countries - in an analysis of patients recruited in Poland included in the IST trial, 14-day case fatality was $13 \%$ (the rate for other IST countries was $9.6 \%$ ) and the proportion of dead patients at six months after stroke was $30 \%$, the highest among all IST countries $[13,25]$. The main reasons for such unfavourable results were considered poorer condition at the onset of stroke, unsatisfactory control of numerous risk factors, delayed rehabilitation and ineffective prevention of acute stroke complications $[12,13,26]$. However, in the next decade stroke care in Poland greatly improved. The National Programme of Prevention and Treatment of Stroke was established, supported by the Ministry of Health, leading to implementation of the stroke unit network with 24-hour CT access and possible thrombolytic treatment [14]. Data from the Polish National Stroke Prevention and Treatment Registry showed only a $15.2 \%$ death rate. This was achieved as a consequence of admission to hospital of more than $40 \%$ of patients within the first 6 hours from stroke onset and treating $67 \%$ of patients in stroke units. Eighty-two percent of all patients were given antiplatelets, and $37 \%$ of patients with atrial fibrillation were treated with anticoagulants. Physiotherapy was performed in more than $80 \%$ of patients. Most patients with a fatal outcome died due to stroke-related causes, not comorbidities [13]. Data obtained in the previously mentioned study in Cracow revealed similar improvement in stroke management, with 30-day case fatality at $17.8 \%$ [21]. In Zabrze, 28 -day case fatality was $18.3 \%$ for all stroke patients and $16.6 \%$ for patients with the first stroke in their history. These values, even taking into account methodological differences, especially the retrospective design of our study, are comparable with current rates from population-based studies in the UK [4], Finland [27] and the USA [23], though worse than in Sweden [28] and France [6].

\section{Conclusions}

1. In this urban population of a city in southern Poland, we established incidence rates comparable to those reported previously in Poland.

2. The high case fatality rate responsible for the previously reported high stroke mortality in Poland decreased more than two-fold in the last decade, probably as a result of improved acute stroke care and hospitalization of all stroke patients.

\section{Disclosure}

The authors report no conflict of interest.

\section{References}

1. Rosamond W., Flegal K., Furie K., et al. American Heart Association Statistics Committee and Stroke Statistics Subcommittee. Heart disease and stroke statistics - 2008 update: a report from the American Heart Association Statistics Committee and Stroke Statistics Subcommittee. Circulation 2008; 117: e25-e146.

2. Broderick J.P. Stroke trends in Rochester, Minnesota, during 1945 to 1984. Ann Epidemiol 1993; 3: 476-479.

3. Thorvaldsen P., Asplund K., Kuulasmaa K., et al. Stroke incidence, case fatality, and mortality in the WHO MONICA Project. Stroke 1995; 26: 361-367.

4. Rothwell P.M., Coull A.J., Giles M.F., et al. Oxford Vascular Study: Change in stroke incidence, mortality, case-fatality, severity, and risk factors in Oxfordshire, UK from 1981 to 2004 (Oxford Vascular Study). Lancet 2004; 12: 1925-1933.

5. Sivenius J., Tuomilehto J., Immonen-Räihä P., et al. FINSTROKE study. Continuous 15-year decrease in incidence and mortality of stroke in Finland: The FINSTROKE Study. Stroke 2004; 35: 420-425.

6. Benatru I., Rouaud O., Durier J., et al. Stable stroke incidence rates but improved case-fatality in Dijon, France, from 1985 to 2004. Stroke 2006; 37: 1674-1679.

7. Pessah-Rasmussen H., Engström G., Jerntorp I., et al. Increasing stroke incidence and decreasing case fatality, 1989-1998: a study from the stroke register in Malmö, Sweden. Stroke 2003; 34: 913-918.

8. Korv J., Roose M., Kaasik A.E. Changed incidence and casefatality rates of first-ever stroke between 1970 and 1993 in Tartu, Estonia. Stroke 1996; 27: 199-203.

9. Feigin V.L., Wiebers D.O., Whisnant J.P., et al. Stroke incidence and 30-day case-fatality rates in Novosibirsk, Russia, 1982 through 1992. Stroke 1995; 26: 924-929.

10. Mihálka L., Smolanka V., Bulecza B., et al. A population study of stroke in West Ukraine. Incidence, stroke services and 30-day case fatality. Stroke 2001; 32: 2227-2231.

11. Ryglewicz D. Epidemiology of stroke: a prospective community-based study of stroke in Warsaw, 1991-1992. Neurol Neurochir Pol 1994; 28 (Suppl 1): 35-49.

12. Ryglewicz D., Hier D.B., Wiszniewska M., et al. Ischemic strokes are more severe in Poland than in the United States. Neurology 2000; 54: 513-515.

13. Czlonkowska A., Niewada M., Saleh El-Baroni I., et al. High early case fatality after ischaemic stroke in Poland: exploration of possible explanations in the International Stroke Trial. $J$ Med Sci 2002; 15: 53-57.

14. Niewada M., Skowrońska M., Ryglewicz D., et al. Polish National Stroke Prevention and Treatment Collaborative Group. Acute ischemic stroke care and outcome in center participating in the Polish National Stroke Prevention and Treatment Registry. Stroke 2006; 37: 1837-1843. 
15. Sarzyńska-Długosz I., Skowrońska M., Członkowska A. Development of the stroke unit network in Poland - current status and future requirements. Neurol Neurochir Pol 2007; 41: 107-112.

16. Central Statistical Office. http://www.stat.gov.pl/cgi_bin/ demografia $/$ rap? woj $=101 \&$ table $=$ web_lsa\&rok $=2006 \&$ woj $=16 \& \mathrm{pl}=2 \& \mathrm{grw} 5=18$

17. Central Statistical Office. http://www.stat.gov.pl/cps/rde/xbcr/ katow/ASSETS_07p04_01.pdf

18. Sudlow C., Warlow C. Comparing stroke incidence worldwide: what makes studies comparable? Stroke 1996; 27: 550-558.

19. Asplund K., Bonita R., Kuulasmaa K., et al. Multinational comparisons of stroke epidemiology. Evaluation of case ascertainment in the WHO MONICA Stroke Study. World Health Organization monitoring trends and determinants in cardiovascular disease. Stroke 1995; 26: 355-360.

20. Tsiskaridze A., Djibuti M., van Melle G., et al. Stroke incidence and 30-day case-fatality in a suburb of Tbilisi: results of the first prospective population-based study in Georgia. Stroke 2004; 35: 2523-2528.

21. Słowik A., Turaj W., Zwolińska G., et al. Stroke attack rates and case fatality in the Krakow Stroke Registry. Neurol Neurochir Pol 2007; 41: 291-295.

22. The European Registers of Stroke (EROS) Investigators. Incidence of stroke in Europe at the beginning of the 21st century. Stroke 2009; 40: 1557-1563.

23. Broderick J.P., Phillips S.J., Whisnant J.P., et al. Incidence rates of stroke in the eighties: the end of the decline in stroke. Stroke 1989; 20: 577-582.

24. Kleindorfer D., Broderick J., Khoury J., et al. The unchanging incidence and case-fatality of stroke in the 1990s. A populationbased study. Stroke 2006; 37: 2473-2478.

25. Weir N.U., Sandercock P.A., Lewis S.C., et al. Variations between countries in outcome after stroke in the International Stroke Trial (IST). Stroke 2001; 32: 1370-1377.

26. Ryglewicz D., Milewska D., Lechowicz W., et al. Factors predicting early stroke fatality in Poland. Preliminary report of the Polish National Stroke Registry. Neurol Sci 2003; 24: 301-304.

27. Sivenius J., Tuomilehto J., Immonen-Räihä P., et al. Continuous 15-year decrease in incidence and mortality of stroke in Finland: The FINSTROKE Study. Stroke 2004; 35: 420-425.

28. Pessah-Rasmussen H., Engström G., Jerntorp I., et al. Increasing stroke incidence and decreasing case fatality, 1989-1998: a study from the stroke register in Malmö, Sweden. Stroke 2003; 34: 913-918. 